\title{
ASPECTOS CLÍNICOS Y EPIDEMIOLÓGICOS DEL DISTEMPER CANINO. ESTUDIO DE CASOS DIAGNOSTICADOS EN LA CIUDAD DE SANTA FE, ENTRE LOS AÑOS 1998 Y 2009
}

\author{
Pinotti, m. ${ }^{1}$; Gollan, A. ${ }^{1}$; Passeggi, C. $^{1}$ \& Formentini, e. ${ }^{2}$
}

\begin{abstract}
RESUMEN
Un estudio epidemiológico de distemper canino fue realizado en la ciudad de Santa Fe, Argentina, entre los años 1998 y 2009. Se obtuvo información acerca de la presentación de los diferentes signos clínicos de esta enfermedad y la frecuencia de distribución de los casos según mes, estación climática, sexo, tamaño corporal y edad. Los signos clínicos de hipertermia, anorexia, oculares y secreciones respiratorias estuvieron presentes en más del 80\% de los casos. La hipertermia estuvo presente en el $100 \%$ de los pacientes. La anorexia, la blefaritis y la descarga ocular ocurrieron en $96,18 \%, 97,71 \%$ y $88,55 \%$ respectivamente. Aunque no hubo cambios en el tamaño de la población susceptible durante los años, la incidencia fue más alta entre los meses de junio $(9,02 \%)$ y noviembre (22,95\%) y entre el invierno (33.61\%) y primavera (34,43\%). La mayor parte de los casos clínicos se observaron en animales de menos de 2 años de edad (42,31\%), en los machos $(63,08 \%)$ y animales de gran tamaño $(73,64 \%)$. Este estudio aporta elementos para conocer el comportamiento de la enfermedad en el contexto de nuestra región y contribuye a la posibilidad de hacer un diagnóstico diferencial precoz correcto.
\end{abstract}

Palabras clave: distemper canino, epidemiología, Santa Fe.

\section{SUMMARY}

\begin{abstract}
Clinical and epidemiological aspects of canine distemper. Study of cases diagnosed in the city of Santa Fe, between 1998 and 2009.

An epidemiological study of canine distemper was conducted in the city of Santa Fe, Argentina, between the years 1998 and 2009. From a total of 131 canines, information was obtained concerning the presentation of the different clinical signs of this disease and the distribution frequency of the clinical cases by month, climatic station, sex, body size and age. Clinical signs of hyperthermia, anorexia, ocular and respiratory secretions were present in over $80 \%$ of cases. Hyperthermia was
\end{abstract}

1.- Cátedra de Virología. Facultad de Ciencias Veterinarias. Universidad Nacional del Litoral. Kreder 2805. (3080) Esperanza, provincia de Santa Fe. Subsidio Proyectos CAI+D nº 10-14 y 32-206, UNL.

Email: mpinotti@fcr.unl.edu.ar

2.- Cátedra de Farmacología. FCV - UNL

Manuscrito recibido el 19 de junio de 2012 y aceptado para su publicación el 18 de diciembre de 2012. 
present in $100 \%$ of patients. Anorexia, blepharitis and ocular discharge occurred in $96.18 \%, 97.71 \%$ and $88.55 \%$ respectively. Although there was no change in the size of the susceptible population during the years, the incidence of the disease was highest between the months of June (9.02\%) and November (22.95\%) and between winter (33.61\%) and spring (34.43\%). Most of the clinical cases were observed in animals less than two years of age (42.31\%), in males (63.08\%) and large animals (73.64\%). This study provides insight to help clarify the behavior of the disease in the context of our region, and contributes to the possibility of making an early correct differential diagnosis.

Key words: canine distemper, epidemiology, Santa Fe

\section{INTRODUCCIÓN}

El distemper canino, también llamado moquillo o enfermedad de Carré, es considerado la patología vírica más seria que afecta a la especie (Lamb \& Kolakofsky, 2001). Su agente etiológico es el virus del distemper canino (VDC) perteneciente al orden $\mathrm{Mo}$ nonegavirales, familia Paramyxoviridae, género Morbillivirus.

Es una enfermedad de alta morbilidad y mortalidad variable, endémica en el mundo entero, siendo susceptibles a la infección natural la mayoría de los carnívoros terrestres y en particular los miembros de las familias Canidae (perro, perro salvaje, perro australiano, zorro, coyote, lobo y chacal, entre otros) y Mustiladae (comadreja, hurón, visón, zorrillo, tejón, armiño, marta y nutria, entre otros). Es altamente contagiosa y afecta básicamente a cachorros menores a un año, quienes constituyen el grupo etario de mayor susceptibilidad, aunque no están exentos de padecerla caninos en cualquier etapa de su vida.

Los animales infectados eliminan virus a través de sus secreciones corporales desde el séptimo día posinfección, aún aquellos que no presentan signos clínicos. El virus es lábil y poco resistente a las condiciones del medio ambiente (Greene \& Appel, 1998).

Mundialmente se reconoce un solo serotipo. No obstante, circulan varios genotipos de distinta virulencia y tropismo celular (Lamb \& Kolakofsky, 2001). Algunas cepas están asociadas con polioencefalitis, ej.: cepa Snyder Hill, mientras otras inducen leucoencefalitis desmielinizante (LD) ej.: cepas R252 y A75-17 (Krakowka \& Koestner, 1997; Orlando et al., 2008).

Aunque los análisis de secuencia de aislamientos de campo revelan varios clusters de cepas de VDC, en brotes recientes se ha observado una considerable estabilidad genética (Haas et al., 1997; Frisk et al., 1999). La cepa local Arg 23, muestra diferencias que sugieren que dos genotipos patogénicos diferentes de VDC circulan en el país (Gallo Calderon et al., 2007).

La patogenia comienza con el ingreso del virus al organismo por vía aerógena o digestiva, el que actuando directamente sobre el tejido linfoide produce inmunosupresión (Krakowka et al., 1985), lo que facilita su difusión posterior a casi todos los tejidos, pudiendo derivar en una LD (Beineke et al., 2009; Schobesberger et al., 2002).

Dado que el virus afecta a casi todos los órganos y tejidos, los signos clínicos son variados, existiendo diversidad respecto de la duración y la severidad de la presentación, que puede variar desde un cuadro subclínico hasta el desarrollo de una enfermedad grave con o sin signos nerviosos.

El primer pico de temperatura pasa generalmente inadvertido y se presenta entre el 